\title{
The Marine Laboratory \\ Institute Of Marine Science \\ UNIVERSITY OF MIAMI
}

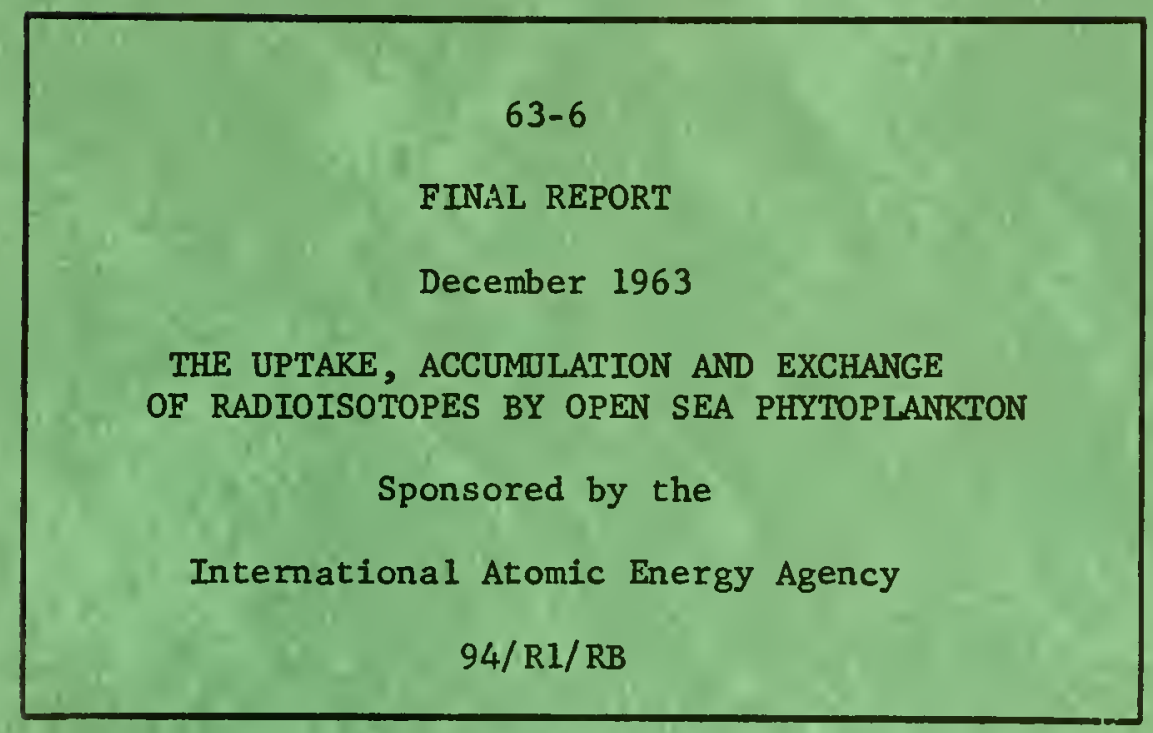

QK

934

C6

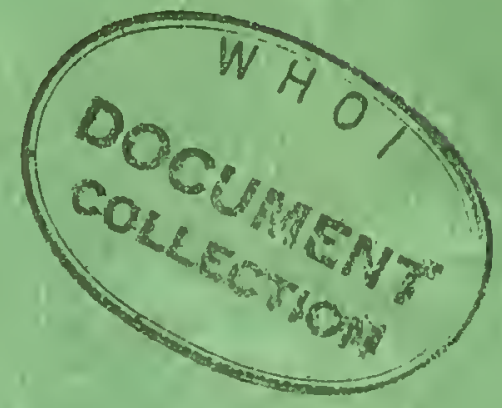

1963 


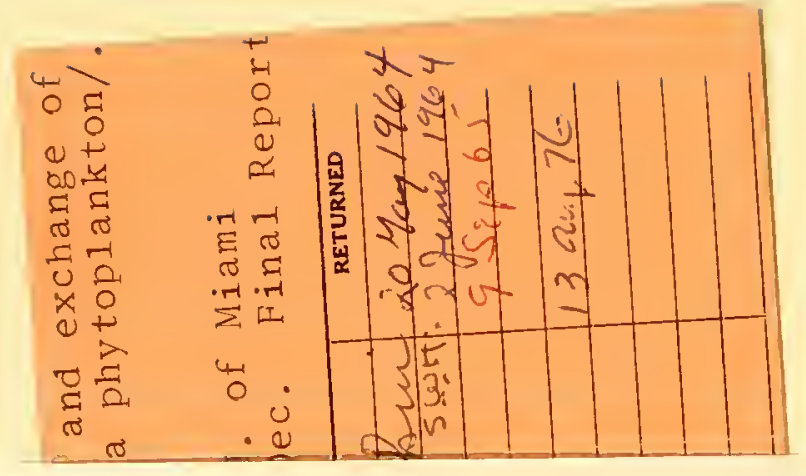




\title{
INSTITUTE OF MARINE SCIENCE \\ The Marine Laboratory \\ University of Miami
}

\author{
$63-6$ \\ Final Report \\ December 1963
}

THE UPTAKE, ACCUMULATION AND EXCHANGE OF RADIOISOTOPES

BY OPEN SEA PHYTOPLANKTON

\author{
Submitted to \\ International Atomic Energy Agency \\ by \\ E. F. Corcoran
}

1 Rickenbacker Causeway Miami, Florida 33149 $8891-4$

ML 63611

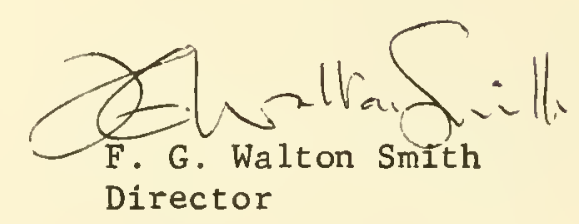





\section{INTRODUCTION}

Since the first nuclear explosion in 1945, the open-sea environment has been subject to an everincreasing supply of radio-chemicals through expanded programs of weapon-testing, accidental sinkings of nuclear-powered ships, and the wastes from land-based and ship-board reactors. While most of these products have extremely short half-lives there are several whose half-lives are of sufficient length to be biologically important. The radionuclides of strontium and cesium are such products. The concentration and vertical distribution of $\mathrm{Sr}^{90}$ and $\mathrm{Cs}^{137}$ have been determined (Bowen and Sugihara, 1960; Miyake, et al. 1962; Rocco and Broeckar, 1963). Both Bowen and Sugihara, and Miyake and his group reported more or less continuous decrease in activity from the surface to great depth, while Rocco and Broecker found an absence of activity between 400 and 1300 meters except in the Anarctic. The highest surface concentration and the greatest penetration was reported by Miyake; they reported concentrations of $\mathrm{Sr}-90$ and $\mathrm{Cs}-137$ in the surface waters of the Pacific of $3.1 \mu \mu \mathrm{c} / \mathrm{L}$ and $4.8 \mu \mu \mathrm{c} / \mathrm{L}$ respectively, and a vertical penetration to $5000 \mathrm{~m}$. Since the distribution and final disposition of these radionuclides can be greatly influenced by marine organisms as they can be utilized along with stable isotopes in their metabolic processes, a study was made of the uptake, accumulation and exchange of these radionuclides by open-sea phytoplankton.

While our knowledge of the mechanisms for the uptake and accumulation of radioisotopes by phytoplankton is still vague and incomplete, studies of organisms found in the effluent from nuclear reactors and in the radioactive sea water following a nuclear explosion have shown plankton capable of concentrating certain radioisotopes from water. Lackey (1957) found that Oedognonium in a settling basin at Oak Ridge National Laboratory had a 
count 10,000 times that of the water in which it was growing. The bluegreen algae growing in the thermal waters of the nuclear reactor effluents of the Savannah River Plant were able to concentrate the mixed fission and corrosion products by factors as great as 10,000 (Watts \& Harvey, 1963) Donaldson, et al in 1956 reported that the plankton from the Bikini test site gave 71,000 counts/g/min which was 7100 times the average surface value of the sea water. A number of investigations were conducted in connection with an underwater test of a nuclear device in the high seas southwest of California. In one of these studies by Thomas, Lear and Haxo laboratory cultures of marine dinoflagellate, Gonyaulax polyedra were placed in sea water obtained from the test site. The organisms were able to concentrate the activity up to 5000 times that found in the sea water. In another study Lear and Oppenheimer showed that Serratia marinorubra cells were grown in the presence of $\mathrm{Sr}-\mathrm{Y}^{90}$ they concentrated the activity from 6000 to 25,000 times. Ninety-five percent of this activity was due to $\mathrm{Y}^{90}$ and $4 \%$ was due to $\mathrm{Sr}^{90}$.

Extensive uptake studies have been carried out by the Fishery Radiobiological Laboratory of the United States Fish and Wildlife Service by 'the Hawaii Marine Laboratory, University of Hawaii, and by IAEA Laboratory of Marine Radioactivity, Monaco. Rice reported in 1956 the differential uptake of radioactive $S r 90$ and $Y 90$ by planktonic algae. He found that Carteria sp. accumulated $\operatorname{sr} 89$ and 90 , while Gyrodinium removed Y90 Erom solution. Nitzschia closterium concentrated Sr90 17 times over normal sea water. Chipman et al., (1958) reported that Nitzschia cells took up large quantities of Zince-65 and Ruthenium-106, but only a limited amount of cesium-137 concentration occurred. Nine marine algae were used and the highest, concentration factor for cesium was 3.1 
Williams and Swanson (1958) and Williams (1960) showed that the uptake of cesium-137 in Euglena and Chlorella was linear with its concentration. Other recent uptake studies include investigations of bacteria by Bernhard (1962), Johnson and Kyker (1961), and Zharova (1961), the uptake and release of cobalt and cesium by soil fungi by Witcamp (1962), a rather extensive. coverage of the absorption of radioisotopes by microorganisms by Morgan (1961).

Related studies being carried on at the Marine Laboratory include the investigation of the uptake, concentration and deposition of $\mathrm{Ca}, \mathrm{Sr}, \mathrm{Y}, \mathrm{Cs}$, Co by marine bacteria, yeasts and fungi. Greenfield (1962) using a Pseudomonas, (B-1) isolated from the shallow waters in South Florida and on the Bahama Banks showed calcium was a growth requirement and that the bacterium could concentrate the cation up to ten times its normal concentration in sea water. When $\mathrm{pH}$ was above 7.5 the pseudomonas, precipitates calcium carbonate in the form of aragonite crystals using either a single or clump of bacteria for a nucleus. Meyers has investigated the ability of several marine fungi to concentrate cesium or cobalt at various growth stages. Extremely low concentration factors were obtained.

\section{METHODS}

In this study of the uptake of radionuclides by open-sea phytoplankton, four radioisotopes have been used, namely, Sr90-Y90, Y-90, Sr-89 and Cs-137. These isotopes were obtained carrier-free from the Oak Ridge National Laboratory operated by the Union Carbide Nuclear Company at Oak Ridge, Tennessee. The phytoplankton used in these studies were cultures obtained from three tropical open-sea environments: 1. The Florida Current 2. The Tongue of the Ocean area, a deep-water area lying south of New Providence Island, and 3. From the At lantic Ocean area northeast of New Providence Island. Water samples 
were obtained with non-toxic Van Dorn or Niskin samplers. Aliquots of $100 \mathrm{ml}$ were enriched with sterile media and incubated under a fluorescent light panel at constant temperature aboard ship. The flasks were placed in a walk-in incubator described below upon return to. the Laboratory. Al1 cultures were grown in the following enrichment medium. potassium nitrate potassium phosphate (dibasic)

ethylene diamine tetraceticacid

tris (hydroxymethy 1 ) aminoethane

soil extract

sea water
10 milligrams

2 mi.11igrams

1 milligram

0.1 milligram

5 milliliters

100 milliliters

The sea water used in the culture medium was collected from the Florida Current, Milipore filtered and sterilized and contained $9 \pm 1$ milligrams of strontium and 0.5 micrograms of cesium per liter. The radioactive isotopes used were carrier-free and did not statistically increase the total content in the sea water. The soil extract was prepared from soil obtained from a sandy mangrove swamp area, this extract contained less than $0.22 \%$ strontium. The cultures were grown in 125 milliliter, Erlenmeyer flasks at $22 \pm 1^{\circ} \mathrm{C}$ and illuminated with General Electric cool-white fluorescent lamps. The light intensity was maintained at 300 foot candles for 18 hours each day. Unialgal cultures were established from these mixed cultures by single cell isolation. For the investigation of the accumulation of strontium and/or yttrium, five stock cultures of oceanic phytoplankton were used. Two unialgal cultures, Gymnodinium simplex (Lohman) and Katodinium rotundata (Lohman) along with three mixed cultutres designated as 4000A, 35A and 10GC, were used. The mixed culture $35 \mathrm{~A}$ contained $\underline{\mathrm{K}}$. rotundata and other phytoflagellate while $10 \mathrm{GC}$ contained both $\underline{K}$. rotundata and $\underline{G}$. Simplex and other small flagellates. 
The culture, 4000A, (Kimball, Corcoran, Wood 1963) was established from a water sample obtained from a depth of 4000 meters at a position 25 miles northeast of Eleuthra. This culture contained 2 species of diatoms, Nitzschia $\underline{\text { seriata }}$ and Navicula sp.

While none of the cultures including the unialgal were bacteria-free, the experiments were designed to reduce the effects directly attributed to bacteria. L. A. Lanskaja (1961) reported that the bacterial population sharply declined during the phase of active phytoplankion division and then began to increase when the maximum growth phase for the phytoplankton was reached. With this in mind, all experiments in this study with Sr90-Y-90 and Cs-137 were conducted during the logarithmic growth phase for each culture. However, the exchange portion of the experiments were allowed to progress into the stationary as well as the death phase since it was of interest to learn how much of the radioisotope would be released upon decomposition.

In growth studies all cultures reached their logarithmic growth phase at two to four days after inoculation. All uptake studies with Sr90 and Y90 were carried out during the logarithmic growth phase. The culture was allowed to grow for four days, then additions of zero, one-fourth, on-half, one, two, five, and ten microcuries carrier-free radioisotope were added. The organisms were exposed to the isotope for 48 hours, since most of the organisms in the cultures demonstrated a 48-hour rythmic pattern of cell division. At the same time a flask of each culture was heat killed by autoclaving and ten microcuries of Sr90-Y90 solution added.

Cell counts were made on the controls and ten $\mathrm{ml}$ aliquots were filtered through tared 25-mm (HA) Millipore filter pad. These filter pads were dried, weighed and counted. The dry cell weight was determined and related to the cell count. 
In addition to biological controls, the medium was checked sorption on the flask walls and MF Filters. Ten ml aliquots of cell-free medium containing the various concentrations of radioisotopes were filtered through Millipore filter pads. Each filter was washed with ten milliliters of distilled water before drying. All dried filter pads were counted with a thin mica window Geiger-Mueller tube using either an Atomic or Berkley Scaler.

Because of the great differences in decay rates and beta energies between Sr90 and Y90 it was possible to determine the differences in selectivity by the cells. Counts were made on each filter disc with an without an aluminum absorber. An aluminum absorber of 222.7 milligrams per square centimeter was used. It was determined that al1 the counts from $\mathrm{Sr}$ wer absorbed while $32.9 \%$ of the $Y$ was counted. Periodic counts were made on the filters with the final count on the 35 th day after filtration. After 35 days the $\mathrm{Y}$ which had been retained by cells had decayed to less than $1 / 1000$ th and the Sr retained had again reached secular equilibrium.

Before proceeding with the uptake study using the radioisotope Cs-137, a preliminary investigation was made of the retention of this isotope on Millipore filter discs. Since differences in counts on Millipore filter discs has been noted in the Sr-Y study, the investigation was to determine whether these differences in counts were due to differences in retention of the cells or the ions. To determine whether or not there was any differences in cell retention by the filter discs, multiple aliquots of two unialgal cultures $\underline{G}$. simplex and D. tertiolecta were filtered onto Millipore filter discs. The. chlorophyl1 a was extracted and was used as an index of Phytoplankton retention. The coefficient of variation for $\underline{G}$. simplex was 8.6 and for $\underline{D}$. tertiolecta was 11.8. From this it was concluded that the differences noted were not from phytoplankton retention but from the variation in amounts of radioisotope 
retained by the filter disc. To test this conclusion three solutions containing Cs 137 were used. The first contained $100 \mathrm{ml}$ of distilled water, the second, $100 \mathrm{ml}$ of millipore-filtered sea water, and the third, $105 \mathrm{ml}$ of millipore-filtered culture media ( $100 \mathrm{ml}$ sea water, $5 \mathrm{ml}$ enrichment medium). Triplicate ten $\mathrm{ml}$ aliquots were withdrawn from each flask and were filtered through HA type millipore filter pads.

In a further attempt to reduce the radioisotope adsorption Millipore filter pads were prewashed with an EDTA* solution or a hydrofluoric acid solution. For this purpose a one per cent solution of hydrofluoric acid or an $\operatorname{EDTA}^{*}(25 \mathrm{mg} / \mathrm{L})$ solution was used.

Following is a tabulation of the results obtained in the study. Table 1

Distilled water with $\mathrm{Cs}-\mathrm{Ba} 137$ added 9,140 counts per ml.
Sea water-millipore filtered with Cs-Bal37 added 18,685 counts per m1.
Culture media-millipore filtered with Cs-Bal37 added 12,755 counts per ml.

\begin{tabular}{|c|c|c|c|c|c|c|c|c|c|}
\hline & $\begin{array}{c}\text { No } \\
\text { prewash }\end{array}$ & $\begin{array}{l}\mathrm{HF}(1 \%) \\
\text { prewash }\end{array}$ & $\begin{array}{c}\text { EDTA } \\
\text { prewash }\end{array}$ & $\begin{array}{c}\text { No } \\
\text { prewash }\end{array}$ & $\begin{array}{l}\mathrm{HF}(1 \%) \\
\text { prewash }\end{array}$ & $\begin{array}{c}\text { EDTA } \\
\text { prewash }\end{array}$ & $\begin{array}{c}\text { No } \\
\text { prewash }\end{array}$ & $\begin{array}{l}\mathrm{HF}(1 \%) \\
\text { prewash }\end{array}$ & $\begin{array}{c}\text { EDTA } \\
\text { prewash }\end{array}$ \\
\hline $\begin{array}{l}c \cdot p \cdot m \text {. } \\
\text { retained }\end{array}$ & 173 & 314 & 136 & 57 & 100 & 45 & 121 & 38 & 45 \\
\hline $\begin{array}{l}\text { on ml- } \\
\text { lipore }\end{array}$ & 147 & 156 & 181 & 56 & 48 & 54 & 23 & 38 & 80 \\
\hline $\begin{array}{l}\text { filter } \\
\text { pads. }\end{array}$ & 242 & 140 & $279 *$ & 70 & 58 & 37 & 17 & 41 & 48 \\
\hline
\end{tabular}

*s: Two washes with EDTA solution and two rinses with distilled water.

* Ethylene diamine tetraacetic acid

From these results it can be seen that Millipore filter discs do retain varying amounts of the isotope, and that prewashing does not appreciably reduce the retention of the isotope.

The amount of adsorption of Cs-137 onto glassware was also checked. In this experiment, $125 \mathrm{ml}$ Pyrex brand Erlenmeyer flasks were used. To insure cleanliness of the glassware, the flasks were washed, rinsed 6 times with tap 
water and twice with distilled water and autoclaved with EDTA solution. After autoclaving, the flasks were rinsed again with distilled water, 50 mil of Millipore-filtered sea water was introduced into each flask and they were again autoclaved at 15 p.s.i. for 15 minutes. When soil extract, M2M, was added to the flasks, this was Millipore-filtered, autoclaved separately and added aseptically to the flasks. Six (6) flasks were used. In flasks 非 1 and 非 $2,1 \mathrm{ml}$ (approx. $10 \mu \mathrm{c}$ ) Cs-137 solution was added to the $50 \mathrm{~m} 1$ sea water, in flasks 非 3 and 非, $1 \mathrm{ml} \mathrm{Cs-137}$ solution and $2.5 \mathrm{ml} \mathrm{M} 2 \mathrm{M}$ soil extract was added to the $50 \mathrm{ml}$ sea water, and in flasks 非 5 and 非6, $2 \mathrm{ml} \mathrm{Cs}-137$ solution, and $2.5 \mathrm{ml}$ M2M soil extract was added to the $50 \mathrm{ml}$ sea water. Immediately, and at 24-hour intervals,200 zaliquots of the solutions were removed from the flasks, placer on stanless steel planchets and dried for counting. The results shown in table 2 show that there was no loss of radioisotope from the medium to the glassware during the 74-hour study.

Table 2

The Loss of Cs-137 from Medium to Glassware

\begin{tabular}{|c|c|c|c|c}
\hline Elask No. & CPM at 0 hours & CPM at 22.5 hours & CPM at 49.5 hrs. & CPM at 74 hrs. \\
\hline & 1106 & 1157 & 1141 & 1100 \\
2 & 1164 & 1163 & 1110 & 1165 \\
3 & 1041 & 1073 & 1165 & 1050 \\
4 & 1107 & 1141 & 1098 & 1066 \\
5 & 2050 & 2060 & 1988 & 2033 \\
6 & 2124 & 2059 & 2214 & 2044 \\
\hline
\end{tabular}

The accumulation and loss studies using the radionuclide, Cs-137 were conducted in much the same manner as were the strontium studies except the cells were washed free of the isotopes before filtration. The phytoplankton cultures used in these experiments were again grown in an enriched sea water medium under controlled light and temperature. 
A preliminary study in which $\underline{G}$. simplex and $\underline{\text { K. }}$ rotundata were used as test organisms showed that $\underline{\mathrm{K}}$. rotundata failed to accumulate the isotope and the uptake by $\underline{G}$. simplex was extremely small. The $\underline{G}$. simplex cells from those preliminary tests were centrifuged and washed three times with sterile sea water and resuspended in fresh medium to determine loss of the iostope.

K. rotundata was not used again for Cs-Ba uptake studies. Further studies were conducted with $\mathrm{G}$. simplex. Eight $125-\mathrm{ml}$ flasks containing 52.5 mls of culture medium were inoculated with $\underline{G}$. simplex and incubated four (4) days or until they were well into their logarithmic growth phase. At that time five milliliters of $\mathrm{Cs}-\mathrm{Ba}^{137}$ solution was added to each flask giving an activity of approximately $25,000 \mathrm{cpm} / \mathrm{ml}$ to the medium.

The accumulation of Cesium-barium-137 by $\underline{G}$. simplex was determined by removing $10 \mathrm{ml}$ aliquot samples after various exposure periods. The cells from the 10-ml sample aliquots were centrifuged out of suspension, washed with sterile sea water, re-centrifuged and resuspended, then filtered onto tared HA type Millipore filter pads, washed with $10 \mathrm{ml}$ distilled water, dried, weighed and counted. Both scintillation and gas-flow counters were utilized. Triplicate samples and duplicate flasks were used for each exposure period. The exposure periods were $24,48,72$ and 96 hours.

The concentration factor was calculated from the result obtained from the 48-hour period to allow a comparison with all the prior studies. The following formula was used to calculate concentration factor.

$$
\text { Conc. factor }=\frac{\mathrm{c} \cdot \mathrm{p} \cdot \mathrm{m} \cdot / \mathrm{gram} \operatorname{cells}}{\mathrm{c} \cdot \mathrm{p} \cdot \mathrm{m} \cdot \mathrm{l} \mathrm{ml} \text { medium }}
$$

The loss of Cs-Ba-137, by cells of $\underline{G}$. simplex and $\underline{N}$. seriata grown in medium containing $\mathrm{Cs}-\mathrm{Ba}{ }^{137}$ for 72 hours was determined when aliquots of cell suspension were placed in 15-ml centrifuge tubes and centrifuged at $1500 \mathrm{rpm}$. 
for 5 minutes. The supernatant was pipetted from the cells and $15 \mathrm{ml}$ of sterile sea water was added. The cells were resuspended in the sterile sea water and the above procedure was repeated three times. When the supernatant was removed after the third centrifugation, the cells were suspended in $2 \mathrm{ml}$ of sterile sea water and added to $52.5 \mathrm{ml}$ of sterile medium in a 125-ml flask. Twelve flasks of each culture were prepared in this way and incubated. After 24,48 and 72 hours, the cells from three flasks of each culture were centrifuged and washed three times with sterile sea water, filtered onto a tared millipore filter and weighed.

Uptake by adsorption of cesium by $G$. simplex and $K$. rotundata. In the studies with the uptake of $\underline{G}$. Simplex it was observed that the rate of uptake was greater during the second 24 -hour period than during the first. This would indicate that adsorption played only a minor role in the uptake of cesium by $\underline{G}$ simplex. On thecother hand, there was the possiblity that the washing technique prior to filtration together with the distilled water wash of the cells while on the filter disc would cause any cesium to be displaced. Therefore a study of the role of adsorption was made.

The adsorption study was conducted in the following manner. Two 250-ml Erlenmeyer flasks, each containing $100 \mathrm{ml}$ of filter sterilized M2M medium (enriched soil extract and natural sea water) were innoculated from a unialgal, bacterial-free culture of $\underline{G}$. simplex and allowed to grow for several days until a fairly dense algal population was obtained. Since $200 \mathrm{ml}$ of algal suspension was needed the two cultures were mixed an then counted. The procedure used to determine adsorption of the algae was to add constant numbers of cells to a constant amount of the isotope for varying lengths of exposure time. The exposure times varied from 3.5 minutes to 178.5 minutes. At the end of the exposure time the cells were removed from the 
media by centrifuging the media at $1500 \mathrm{rpm}$ for 5 minutes. Then a one-ml aliquot was removed from the supernatant liquid and placed in a planchet. To insure consistency, the one-ml samples were diluted with distilled water until it covered the entire surface of the planchet, then it was dried under IR light and stored in a desiccator until it was counted. After sampling, the supernatant was decanted and the $c \in 11$ s resuspended in fresh media. The cells were removed from this media in the same manner and the medium was again sampled. The cells were then resuspended in fresh medium and filtered onto tared Millipore filter discs, dried and stored in a desiccator until counted. The purpose in washing the cells was to compare the activity remaining on the cells after this procedure with the loss of isotope from the medium in the first sample. In this way an evaluation of prior data could be made.

All tests were made in duplicate and all samples were drawn in duplicate. The amount of isotope adsorbed by the algae was determined by comparing the amount of radionuclide remaining in the medium after the initial centrifugation with the control which set up using sterile medium and no cells.

To check the experimental error due to the sampling techniques, duplicate controls were set up. From each of these four one-ml samples were removed and handled in the same manner as described above. The highest percent deviation* observed for either of the positive controls was $6.7 \%$. The calculated percent deviation between the averages of the two controls was less than one percent: The calculated percent deviation of the average of all eight samples was $4.5 \%$. The value of $4.5 \%$ was used as the experimertal error and values falling within the range of plus or minus $4.5 \%$ of the control were considered as equal to the control. The values in the analysis of the data are the averages of the duplicates run on each test exposure time

One additional factor which was investigated was the amount of time 
during centrifugation which should be considered as adding to the exposure time. By cell counts it was found that more than $90 \%$ of the cells are spun out of the medium after one minute at $1500 \mathrm{rpm}$ plus 45 seconds of deceleration time and that $41 \%$ of the cells are removed after 30 seconds of centrifugation at $1500 \mathrm{rpm}$ and 45 seconds deceleration. Therefore, it was decided to add one minute of the centrifugation time to the total exposure time of the cells.

The experiments to determine the uptake of Sr-89 by adsorption to $\underline{G}$. $\underline{\text { simplex }}$ and $\mathrm{K}$. rotundata were conducted in a manner similar to that used with cesium except the organisms were grown in culture tubes instead of Erlenmeyer flasks. For the study with $\underline{G}$. simplex fourteen culture tubes were used. They were grown to a dense population then three tubes were counted to determine the number of cells per $\mathrm{mm}^{3}$. Ten milliliters of cell suspension was used for each experiment. After counting, the cell suspension was filtered onto tared filters, dried, weighed and the cell count related to weight.

In this experiment the cells were exposed to a concentration of $0.2 \mu \mathrm{c} / \mathrm{ml}$ of $\mathrm{Sr}-90$ for the following times: $2,4,10,20,40,60,80$, and 160 minutes. The cells were centrifuged from the medium and duplicate one-ml aliquots of the medium were assayed for loss in radioactivuty. After this the remainder of the medium was removed, and the cells were resuspended in fresh medium and then filtered out of suspension onto tared Millipore filter discs.

No-cell controls were used throughout the experiments and all experiments were made in duplicate. The uptake of Sr-89 by adsorption studies for $\underline{\mathrm{K}}$. rotundata were conducted in the same manner.

\section{EXPERIMENTAL RESULTS}

1. Uptake of Strontium-Yttrium by Various Phytoplankton

The five cultures of open sea phytoplankton were grown in an enriched natural sea water medium to which various amounts of $5 r^{90} \mathrm{Y}^{90}$ solution was 
Table 3. The differential uptake of radioactive strontium and yttrium by marine algae after 48 hours exposure. Six replications each.

\begin{tabular}{|c|c|c|c|}
\hline $\begin{array}{l}\text { Species or } \\
\text { culture number }\end{array}$ & $\begin{array}{l}\text { Microcuries } \\
\text { of Sr90-Y90 } \\
\text { per 11ter } \\
\text { of media }\end{array}$ & $\begin{array}{l}\text { Per cent } \\
\text { activity } \\
\text { from } \\
\text { strontium-90 }\end{array}$ & $\begin{array}{l}\text { Per cent } \\
\text { activity } \\
\text { from } \\
\text { yttrium-90 }\end{array}$ \\
\hline \multirow{6}{*}{ G. simplex } & 5.14 & 5 & 95 \\
\hline & 10.10 & 3 & 97 \\
\hline & 20.18 & 4 & 96 \\
\hline & 40.29 & 4 & 96 \\
\hline & 100.18 & 4 & 96 \\
\hline & 198.53 & 1 & 99 \\
\hline \multirow[t]{6}{*}{ K. rotundata } & 5.14 & 100 & 0 \\
\hline & 10.10 & 100 & 0 \\
\hline & 20.18 & 45 & 55 \\
\hline & 40.29 & 100 & 0 \\
\hline & 100.18 & 100 & 0 \\
\hline & 198.53 & 100 & 0 \\
\hline \multirow[t]{6}{*}{$4000 \AA$} & 5.14 & 2 & 98 \\
\hline & 10.10 & 1 & 99 \\
\hline & 20.18 & 1 & 99 \\
\hline & 40.29 & 1 & 99 \\
\hline & 100.18 & 1 & 99 \\
\hline & 198.53 & 1 & 99 \\
\hline \multirow[t]{6}{*}{$35 \mathrm{~A}$} & 5.14 & 1 & 99 \\
\hline & 10.10 & 3 & 97 \\
\hline & 20.18 & 2 & 98 \\
\hline & 40.29 & 1 & 99 \\
\hline & 100.18 & 1 & 99 \\
\hline & 198.53 & 3 & 97 \\
\hline \multirow[t]{6}{*}{$10 \mathrm{G} . \mathrm{C}$. } & 5.14 & 10 & 90 \\
\hline & 10.10 & 8 & 92 \\
\hline & 20.18 & 3 & 97 \\
\hline & 40.29 & 3 & 97 \\
\hline & 100.18 & 6 & 94 \\
\hline & 198.53 & 5 & 95 \\
\hline
\end{tabular}


added to determine whether or not there was selective uptake of strontium or yttrium by the organisms. After 48 hours of exposure during the active growth phase, aliquots of cells were filtered onto Millipore filter discs washed, dried and counted. Table 3 shows the differential uptake by the various phytoplankton. The two organisms, $\underline{G}$. simplex and $\underline{K}$. rotundata grown in unialgal cultural showed remarkable ability to select nuclides. Nearly all the radioactivity (95 to 99 percent) found in $\underline{G}$. simplex was due to yttrium while that found in $\underline{\mathrm{K}}$. rotundata was only from strontium. Confirmation of the results of this experiment were obtained with a duplicate experiment in which carrier-free yttrium-90 was used. Similar results to these were obtained by Rice (1956) when he found that 10 out of 12 species of algae investigated selected yttrium from the medium.

Figure 1 through 5 show the concentration of strontium-90 accumulated per gram of cells that were grown in media containing up to 200 microcuries per liter. Here it can be seen that during the 48-hour exposure the accumulation of strontium-90 by the organisms is proportional to the concentration of the radionuclide in the medium.

The concentration factors for strontium-90 are shown in table 4. Here the differences in selectivity are indicated by their abilities to accumulate strontium. K. rotundata concentrated the strontium exclusively while $\underline{\text { G }}$ simplex and the other three cultures indicated their preference for yttrium by their small factors. During the 48 -hour study $\underline{K}$. rotundata was able to concentrate strontium-90 about 382 times that of the medium in which they were grown, while the $4000 \mathrm{~A}$ culture which contained mainly diatoms had a concentration factor of on 1y 21.5. These results are similar to those obtained by Rice (1956) where he found a concentration factor of 17 for Nitzchja. 
Table 4. Average concentration of radioactive strontium by marine algae after 48 hours exposure.

Species or
Culture No.
$\frac{\mathrm{G}}{\mathrm{K}} \cdot \frac{\text { simplex }}{\mathrm{r} o t u n d a t a}$
$3000 \mathrm{~m} \mathrm{~A}$.
$10 \mathrm{~m} \mathrm{G.C.}$

Species or

G. simplex

K. rotundata

$4000 \mathrm{~m} \mathrm{~A}$.

$10 \mathrm{~m} \mathrm{G} . \mathrm{C}$.

\author{
Concentration \\ Factor \\ $18.6 \pm 2.3$ \\ $381.7 \pm 51.5$ \\ $21.5 \pm 4.6$ \\ $24.3 \pm 2.6$ \\ $29.3 \pm 7.0$
}

2. The effect of strontium concentration on uptake.

To find the effect of higher concentrations of strontium on the uptake of the strontium and to determine whether or not the uptake of radioactive strontium had been due to strontium-starved cells, cultures were grown in media which contained up to $110 \mathrm{mg}$ Sr/liter. Ten microcuries of strontium-90 solution was introduced into the actively growing culture ( 4 days) and the cultures continued for another 48-hour period. At that time a 10-ml aliquot was filtered onto a millipore filter disc and dried over silica gel. The dry filter discs were counted under a thin-mica window G-M tube. These experiments showed that the addition of higher concentrations (up to 10 times natural sea water) of stable strontium had no toxic effect on the culture. The growth of the cultures was as good as those grown in natural sea water. With the exception of $\underline{\mathrm{K}}$. rotundata the increased concentrations had little effect on the uptake of radioactive strontium (Figure 6). The uptake of $\underline{\mathrm{K}}$. rotundata seemed to be depressed slightly by the higher strontium concentration.

3. Uptake of strontium by dead and living cells.

A subculture of each of the five selected test cultures was allowed to progress into the logarithmic growth phase (4 days), and at that time was heat killed by autoclaving for 15 minutes at 15 p.s.i. Each subculture was then inoculated with $10 \mu \mathrm{c}$ of strontium-90 solution. After 48 hours exposure 


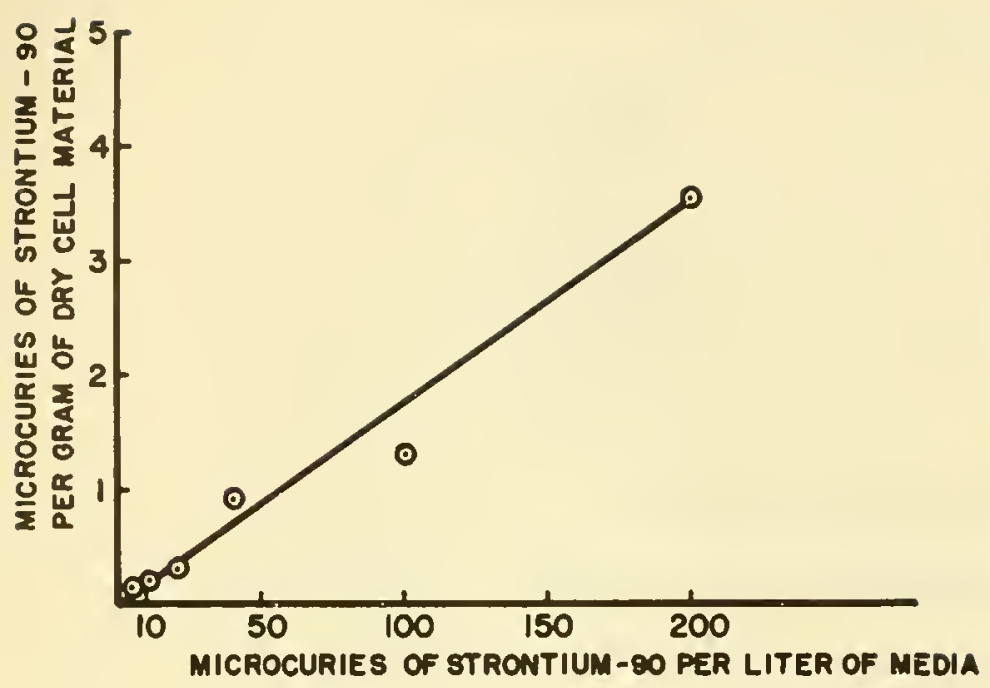

Figure 1. Uptake of radioactive stront1um in relation to 1 ts concentration 1 in the medium by $\underline{G}$. simplex after 48 hours exposure. Single determinations plotted.

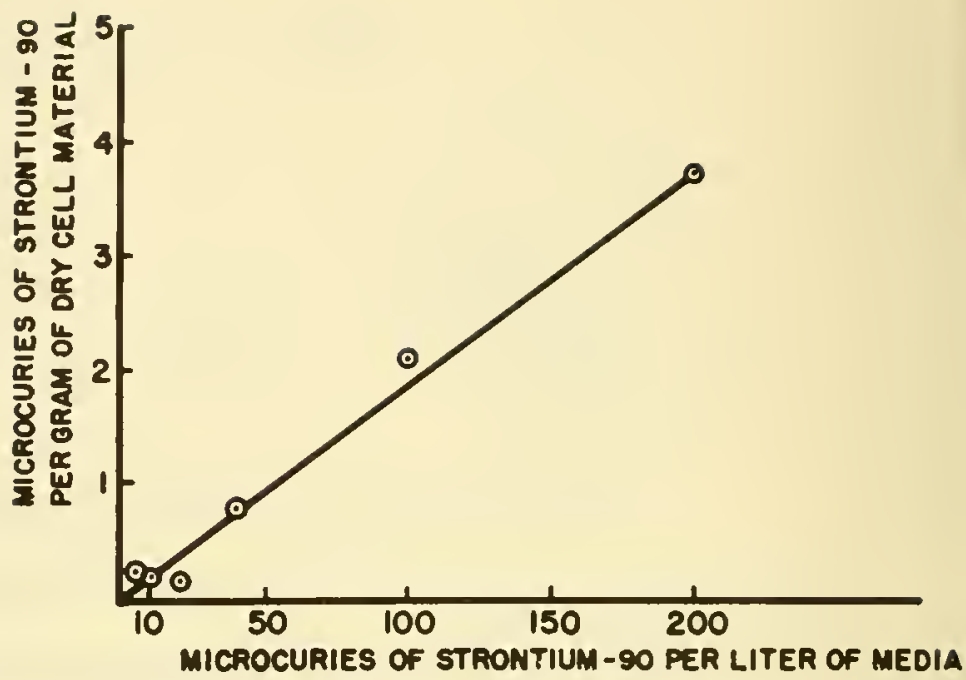

Figure 2. Uptake of radioactive strontium in relation to 1 ts concentration in the medium by culture 4000 A after 48 hours exposure. Single determinations plotted.

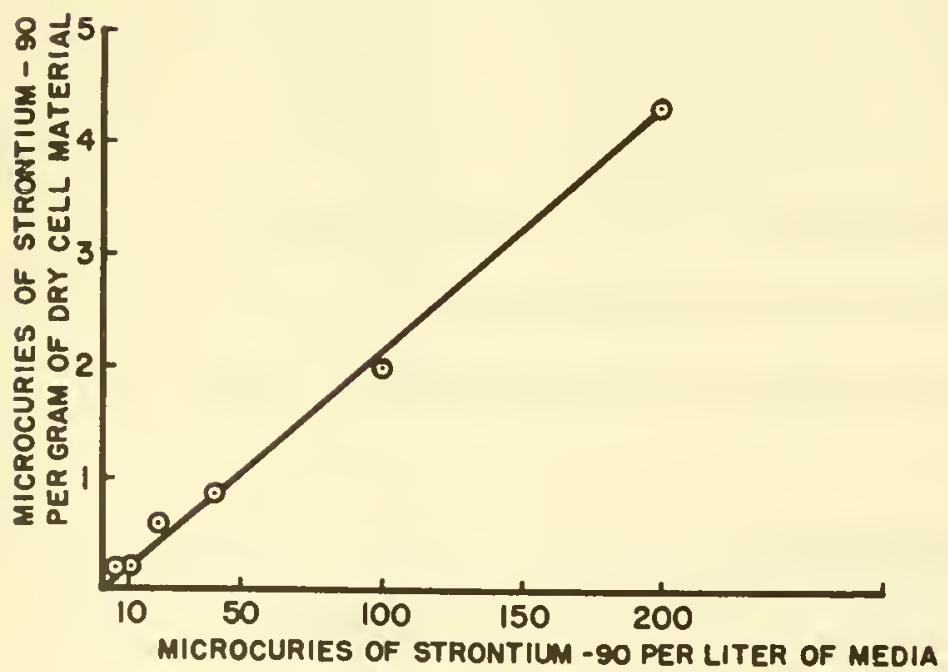

Figure 3. Uptake of radioactive strontium in relation to 1 to concentration in the medium by culture 35 A after 48 bours exposure. Single determinations plotted.

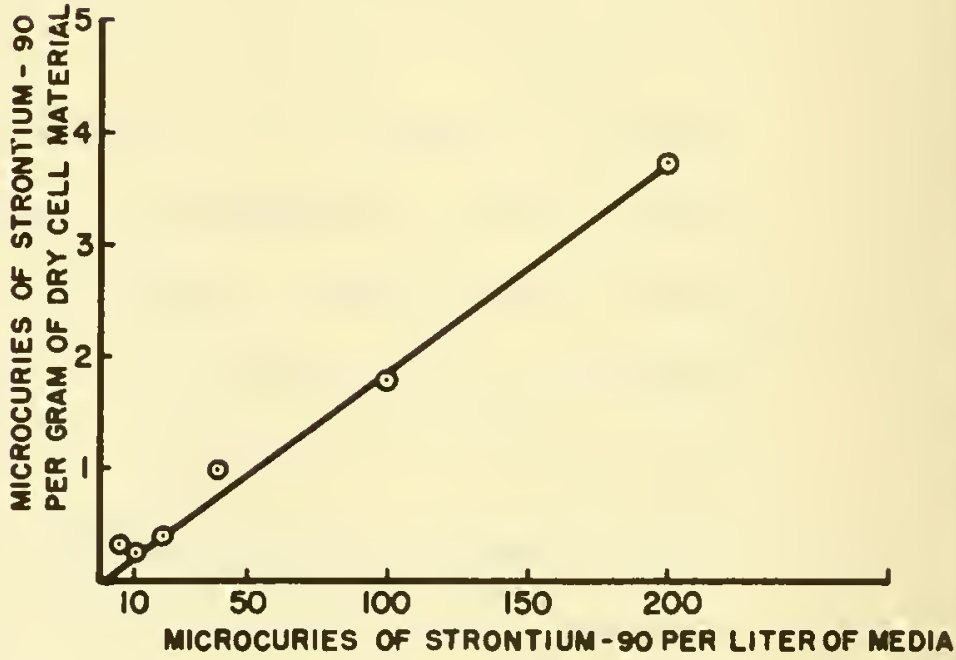

Pigure 4. Uptake of radioactive strontiue in relation to its concentration in the mediun by culture $10 \mathrm{G} . \mathrm{C}$. after 48 hours exposure. Single determinations plotted. 
the cell material was filtered onto a tared millipore disc, dried, counted and weighed. The results of the uptake studies conducted on the heat killed cells are given in Table 5 and 6 . While it was previously noted that living cells could clearly demonstrate an ability to differentiate between strontium and yttrium, the adsorption by heat killed cells showed no such selectivity. With the exception of $\underline{\mathrm{K}}$. rotundata the accumulation of strontium- 90 by the organisms which had been heat killed was nearly equal to that which had been accumulated by the living cells during the same length of time (Table 6). This would seem to indicate that adsorption or ion exchange may play a role in the accumulation of ions. Since heat killing does bring about changes in the cell wall, it is difficult to determine whether the accumulation was an adsorptive process.

Table 5. Accumulation of radioactive strontium and yttrium by heat killed cells after 48 hours exposure.

\section{Species or}

Culture No.

\section{$\%$ Activity}

From Sr.
$\%$ Activity

From Yttrium
G. simplex

$\overline{\mathrm{K}}$.

$4000 \mathrm{~m} \mathrm{~A}$.

$35 \mathrm{~m} \mathrm{~A}$.

$10 \mathrm{~m} \mathrm{G} . \mathrm{C}$.
3

2

4

3

4
97

98

96

97

96

Table 6. Comparison of the radioactive strontium accumulated by living and heat killed cells after 48 hours exposure.

Species or

Culture No.
Living Cells

$\mu \dot{c} / \dot{g}$ dry weight
Dead Ce11s

$\mu \mathrm{c} / \mathrm{g}$ dry weight
G. simplex

$\overline{\mathrm{K}}$. rotundata

$4000 \mathrm{~A}$

$35 \mathrm{~A}$

10 G. C.
3.5

40.7

3.7

4.3

3.7
3.3

4.5

4.7

4.3

3.8 
4. The Accumulation of $\mathrm{Cs}-\mathrm{Ba}^{137}$ by Various Phytoplankton

The uptake studies using $\mathrm{Cs}-\mathrm{Ba}^{137}$ were conducted in much the same manner as those used for the strontium-yttrium studies except that the cells were washed free of the isotope by an elaborate washing process before filtration. Preliminary studies with the unialgal cultures showed that $\underline{\text { K. }}$ rotundata failed to accumulate cesium so this organism was not used in the study. G. simplex and Nitzchia speriata were the unialgal cultures used. Triplicate samples from duplicate flasks were withdrawn each 24 hours after the initial exposure to the radioisotope up to 96 hours. The results of this study for $\underline{G}$. simplex are shown in table 7 .

Table 7. The accumulation rate of $\mathrm{Cs}-\mathrm{Ba}{ }^{137}$ by $\mathrm{G} \cdot \underline{\text { simplex }}$ (medium: $2.5 \times 104 \mathrm{cpm} / \mathrm{m} 1$ )

\begin{tabular}{|c|c|c|c|c|c|c|c|c|c|c|c|}
\hline Time & $\begin{array}{l}\mathrm{cpm} / \mathrm{g} \\
\mathrm{ce} 11 \mathrm{~s} \\
\left(\mathrm{x} 10^{4}\right)\end{array}$ & $\begin{array}{r}\text { Conc. } \\
\text { factor }\end{array}$ & Avg. & Time & $\begin{array}{l}\mathrm{cpm} / \mathrm{g} \\
\mathrm{ce} 11 \mathrm{~s} \\
\left(\times 10^{4}\right)\end{array}$ & $\begin{array}{r}\text { Conc. } \\
\text { factor }\end{array}$ & Avg. & Time & $\begin{array}{l}\text { cpm/g } \\
\text { ce } 11 \mathrm{~s} \\
\left(\times 10^{4}\right)\end{array}$ & $\begin{array}{r}\text { Conc. } \\
\text { factor }\end{array}$ & Avg. \\
\hline \multirow{6}{*}{$\begin{array}{c}24 \\
\text { hours }\end{array}$} & 7.2 & 2.88 & \multirow{6}{*}{$\begin{array}{l}2.5 \pm \\
15 \%\end{array}$} & \multirow{6}{*}{$\begin{array}{l}48 \\
\text { hours }\end{array}$} & 40.8 & 16.3 & \multirow{6}{*}{$\begin{array}{l}13.8 \pm \\
16 \%\end{array}$} & \multirow{6}{*}{$\begin{array}{c}72 \\
\text { hours }\end{array}$} & 17.8 & 7.1 & \multirow{6}{*}{$\begin{array}{l}9.4 \pm \\
20 \%\end{array}$} \\
\hline & 6.2 & 2.48 & & & 34.1 & 13.6 & & & 21.6 & 8.6 & \\
\hline & 6.0 & 2.40 & & & 27.1 & 10.9 & & & 20.4 & 8.2 & \\
\hline & 6.7 & 2.68 & & & 35.5 & 14.2 & & & 25.9 & 10.4 & \\
\hline & 4.9 & 1.96 & & & 29.1 & 11.6 & & & 32.5 & 13.0 & \\
\hline & & & & & 40.4 & 16.2 & & & 26.5 & 10.6 & \\
\hline
\end{tabular}

The 48-hour concentration factor for $\underline{G}$. simplex was found to be $13.8 \pm$ $16 \%$. The rate of uptake was greater during the second 24 -hour period than it was during the first. During the first 24 hours to cells had accumulated on ly about 2.5 times that of the medium while this increased to almost 14 during the second 24 hour period. At the end of 72 hours however, the rate of accumulation again decreased to a factor of 9.4. This increase in rate of accumulation followed by a decrease is probably due to the culture being 
somewhat synchronous in respect to cell division. If this is true, and the cell weight increase is constant throughout the growth period then weight increase would be greater in respect to uptake during the early phase of cell growth. This would account for some of the observed difference in uptake rate.

The same procedure was used for the study of the accumulation of $\mathrm{Cs}-\mathrm{Ba}^{137}$ by $\underline{N}$. seriata as was used with $\underline{G}$. simplex except the samples were withdrawn at 24,56 and at 72 hours. The rate of uptake of the Cs-Ba isotope by $\mathrm{N}$. seriata was extremely low, but did show a gradual increase over the 72-hour period. The results of the counts together with the concentration factors are tabulated in table 8 .

Table 8 . The accumulation rate of $\mathrm{Cs}-\mathrm{Ba} 137$ by $\underline{\mathrm{N}}$. Seriata (medium: $10.2 \times 10^{4} \mathrm{cpm} / \mathrm{ml}$ )

\begin{tabular}{|c|c|c|c|c|c|c|c|c|c|c|c|}
\hline Time & $\begin{array}{l}\mathrm{cpm} / \mathrm{g} \\
\mathrm{ce} 11 \\
\left(\times 10^{4}\right) \\
\end{array}$ & $\begin{array}{l}\text { Conc. } \\
\text { factor }\end{array}$ & Avg. & Time & $\begin{array}{l}\text { cpm/g } \\
\text { ce } 11 \\
\left(\times 10^{4}\right)\end{array}$ & $\begin{array}{r}\text { Conc. } \\
\text { factor }\end{array}$ & Avg. & Time & $\begin{array}{l}\text { cpm/g } \\
\text { ce } 11 \\
\left(x 10^{4}\right)\end{array}$ & $\begin{array}{r}\text { Conc. } \\
\text { factor }\end{array}$ & Avg. \\
\hline \multirow{6}{*}{$\begin{array}{c}24 \\
\text { hours }\end{array}$} & 2.1 & .21 & \multirow{6}{*}{$29 \%$} & \multirow{6}{*}{$\begin{array}{l}56 \\
\text { hours }\end{array}$} & 3.7 & .36 & \multirow{6}{*}{$\begin{array}{l}.46 \pm \\
17 \%\end{array}$} & \multirow{6}{*}{$\begin{array}{c}72 \\
\text { hours }\end{array}$} & 7.6 & .75 & \multirow{6}{*}{$\begin{array}{l}.70 \pm \\
11 \%\end{array}$} \\
\hline & 3.9 & .38 & & & 3.7 & .36 & & & 7.4 & .73 & \\
\hline & 2.8 & .27 & & & 5.7 & .56 & & & 7.6 & .75 & \\
\hline & 5.1 & .50 & & & 4.9 & .48 & & & 5.4 & .53 & \\
\hline & 4.1 & 40 & & & 4.1 & 40 & & & 7.4 & $73^{-}$ & \\
\hline & 3.3 & .32 & & & 4.7 & .46 & & & 7.3 & .72 & \\
\hline
\end{tabular}

These results are similar to those obtained by Williams and Swanson (1958). They found that when Chlore11a was grown in a medium which contained stable cesium, the concentration factor was approximately unity. They also found that the amount of potassium in the medium had an effect on the concentration of cesium accumulated by the organisms. They indicated that cesium and potassium formed a pool and that potassium in the medium depressed the 
the accumulation of the cesium. Since this study was conducted in enriched natural sea water medium no attempt was made to determine the effect of potassium concentration on the accumulation of cesium. The medium contained a concentration of $1.5 \mu g$ of cesium/liter (Smales, 1955) and $388 \mathrm{mg} /$ liter of potassium from the sea water and $47.6 \mathrm{mg} /$ liter of potassium from the added nutrients. This high potassium concentration undoubtedly accounts for the low concentration factors. These experiments should be repeated in defined medium where potassium salts are not used for enrichment.

\section{The loss of Cs-Bal37 from Various Phytoplankton.}

To study the loss of cesium-barium isotope to the medium, cells of $\underline{G}$. simplex and $\underline{N}$. seriata were grown in medium containg Cs-Ba-137 for 72 hours then were resuspended in fresh medium according to the procedure described in the Methods section. After 24, 48, and 72 hours samples were removed and the loss of radioactivity was calculated.

The cells of $\underline{G}$. simplex showed a weight loss during the first 24 hour period which was followed by steadily increasing weight thereafter.

Figure 7 shows a plot of the radioactivity from $\mathrm{Cs}-\mathrm{Ba}-137$ in average counts per minute per milligram of cell material starting 24 hours after the radioactive cells were introduced into the fresh medium. This figure also shows the calculated values for the loss in radioactivity due to the increase in cell weight and the difference between the two values (observed and calculated). This shows that there is a loss of radioactivity from the cells during the first 24 hour period of active cell growth, and that a steady state seems to be established after that.

The results from the study with $\underline{N}$. seriata showed that there was an increase in the amount of radioactivity per milligram of cell material. This would indicate that the actively growing older cells continued to 
remove Cs-Ba-137 from the medium. Apparent $1 \mathrm{y}, \mathrm{Cs}-\mathrm{Ba}-137$ was returned to the medium from lysed cells during the initial growth period. Had the culture been bacteria-free this problem would have been eliminated, Nitzchia continues to slowly accumulate cesium from the medium as long as any is available.

\section{The Uptake of Cesium and Strontium by Adsorption}

In the study to determine the accumulation Cesium by $\underline{G}$. simplex it was observed that the rate of uptake was greater during the second 24-hour period than it was during the first. This would seem to indicate that even though the experiments with dead and living cells showed the possiblity of adsorption, the role was probably a minor one. While no prior studies had been made of the role of adsorption by phytoplankton cells, yeast cells had been studied. Rothstein and Hayes (1956) reported "That the presence of various fixed anionic groups on the surface of the yeast cell should confer upon it, ionbinding properties similar to those of ion-exchange resins". They also found that bivalent ions with the exception $\mathrm{UO}_{2}^{+}$formed a complex with the cellular groups that was of the same order of stability as that of the $\mathrm{Mn}^{++}$complex and that a large proportion of the cation was bound in less than 2 minutes (tests up to 180 minutes added on $1 y$ 6\% more). They summarized their findings in the following way: (1) binding of exogenous bivalent and univalent cations by the yeast cell was rapid and reversible, obeying a simple mass law equation (2) bivalent cations were bound more firmly than univalent cations, and (3) the binding sites were located on the periphery of the cell. Thus if the cells obey a simples mass-action law in adsorbing cations from the medium the comparatively greater amounts of univalent cations together with the more readily attracted bivalent cations found in sea water would tend to limit the adsorption of cesium. On the other hand there was the possiblity the washing technique prior to filtration was removing any adsorbed cesium, and thus the uptake value would reflect absorption only. Hence, experiments 
(see Methods) were designed to test the adsorption of cesium and strontium onto the cell wall. The exposure times for cesium varied from 3.5 minutes to 178.5 minutes and the intervals of $2,4,10,20,40,80$ and 160 minutes were used with strontium- 89 .

The results from the cesium experiment revealed that neither $\underline{G}$. simplex nor $\underline{\mathrm{K}}$. rotundata removed cesium from the medium up to 178.5 minutes. The adsorption of $\mathrm{Sr}-89$ by $\underline{G}$. Simplex would seem to play no part in the uptake of strontium by this organism. The only indication of any uptake occurred in exposure times of 80,160 and 160 minutes. And even then there was less than $4 \%$ difference in the counts. While $\underline{\mathrm{K}}$. rotundata in prior experiments showed a remarkable ability to concentrate strontium, there was no uptake by adsorption. The results of these two experiments are shown in tables 9 and 10.

\section{The Culture of Phytoplankton in Defined Medium}

Since it is impossible to control the various ion concentrations in a culture medium when natural sea water is used, an extensive investigation into defined culture media was made. In addition to a literature search into the various synthetic media which had been successfully used for the culture of phytoplankton, the following authorities were personally contacted: Bruce Parker of the University of Southern California, John McLaughlin from Haskins Laboratory, Michael Bernhard from La Spezia and Carl Oppenheimer of our own Laboratory. Early success in growth of unialgal cultures of Amphidinium sp. (operculatum) and Katodimum sp. rotundata was achieved with Haskins Laboratory medium formula ASP82. However, this did not provide growth for G. simplex. Guillards synthetic medium was tried also for $\underline{G}$. simplex without success. Neither of the above media supported growth as well natural sea water media. This was thought to be due to the low concentrations of potassium 
Table 9. The Uptake of $\mathrm{Sr}-89$ through Adsorption by $\underline{G}$. simplex

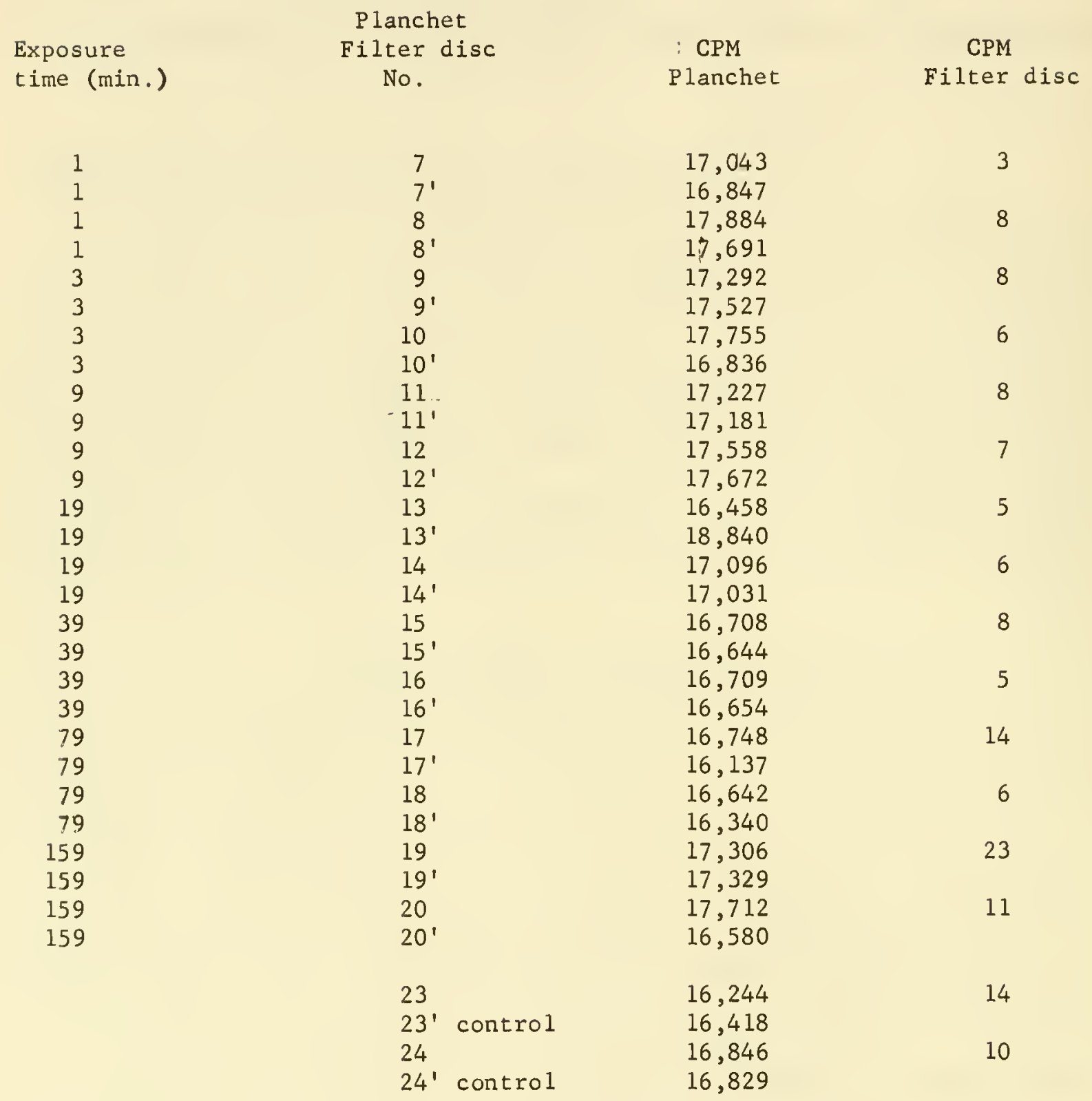


Table 10. The Uptake of Sr-89 through Adsorption by $\underline{K}$. rotundata

\begin{tabular}{|c|c|c|c|}
\hline $\begin{array}{l}\text { Exposure } \\
\text { time (min.) }\end{array}$ & $\begin{array}{c}\text { Planchet \& } \\
\text { Filter disc } \\
\text { No. }\end{array}$ & $\begin{array}{c}\text { CPM } \\
\text { Planchet }\end{array}$ & $\begin{array}{c}\text { CPM } \\
\text { Filter disc }\end{array}$ \\
\hline 1 & 7 & 11,624 & 1 \\
\hline 1 & $7^{\prime}$ & 11,546 & \\
\hline 1 & 8 & 11,760 & 1 \\
\hline 1 & $8^{\prime}$ & 11,706 & \\
\hline 3 & 9 & 11,648 & 1 \\
\hline 3 & $9^{\prime}$ & 11,719 & \\
\hline 3 & 10 & 12,067 & 0 \\
\hline 3 & $10^{\prime}$ & 12,075 & \\
\hline 7 & 11 & 11,181 & 3 \\
\hline 7 & $11^{\prime}$ & 11,159 & \\
\hline 7 & 12 & 11,434 & 4 \\
\hline 7 & $12^{\prime}$ & 11,305 & \\
\hline 7 & 13 & 11,422 & 0 \\
\hline 15 & $13^{\prime}$ & 11,130 & \\
\hline 15 & 14 & 11,420 & 2 \\
\hline 15 & $14^{\prime}$ & 11,386 & \\
\hline 39 & 15 & 11,327 & 0 \\
\hline 39 & $15^{\prime}$ & 11,330 & \\
\hline 39 & 16 & 11,237 & 1 \\
\hline 39 & $16^{\prime}$ & 11,044 & \\
\hline 70 & 17 & 11,335 & 1 \\
\hline 79 & $17^{\prime}$ & 11,308 & \\
\hline 79 & 18 & 11,306 & 3 \\
\hline 79 & $18^{\prime}$ & 11,472 & \\
\hline 159 & 19 & 11,446 & 5 \\
\hline 159 & $19^{\prime}$ & 11,526 & \\
\hline 159 & 20 & 11,289 & 2 \\
\hline \multirow[t]{5}{*}{159} & $20^{\prime}$ & 11,235 & \\
\hline & 23 contro 1 & 11,180 & 3 \\
\hline & $23^{\prime}$ control & 11,129 & \\
\hline & 24 control & 11,329 & 3 \\
\hline & $24^{\prime}$ control & 11,302 & \\
\hline
\end{tabular}


and phosphate-phosphorus. Research was continued in development of a good phytoplankton medium until at present a very successful medium has been developed. The formula for this synthetic medium is shown in table 11 be low. Slightly better growth from certain organisms has been realized when 2.54 grams of sodium chloride was substituted for 1.8 grams.

\section{SUMMARY AND CONCLUSIONS}

A 2 1/2 year study has been made of the uptake, accumulation and exchange of the radioisotope $\mathrm{Sr}^{90}-\mathrm{Y}^{90}, \mathrm{Y}^{90}, \mathrm{Sr}^{90}$ and $\mathrm{Cs}^{137}-\mathrm{Ba}^{137}$ by tropical oceanic phytoplankton and many of the parameters which influence these phenomena. It was apparent after reviewing much of the literature which concerned the uptake of various nuclides by microorganisms that the conditions and procedures varied from laboratory to laboratory. In fact, so many different procedures, or lack of procedures and condition were reported that comparison of results was very difficult. It was therefore, necessary to investigate the parameters which affect the uptake, accumulation and loss of radionuclides by phytoplankton as the study progressed. Such parameters as light, temperature, and medium were kept constant while retention of the radioisotopes by filter discs, the adsorption of the isotope on glassware have been investigated. Every effort has been made to describe the procedure developed and the results obtained in these investigations so that this information might be utilized in future studies.

All the organisms used in these studies are representative of the open sea environment. While in the early work the cultures contained some bacteria, their affect was minimized through selected conditions. In all later research, the cultures were free of bacteria. All experiments were conducted with healthy, actively growing organisms usually during their logarithmic growth phase.

The results of this study show that all the organisms tested were capable 
Table 11. Synthetic Medium for Phytoplankton Culture (T-1)

$\mathrm{NaC} 1$

$\mathrm{MgSO}_{4} 7 \mathrm{H}_{2} \mathrm{O}$

$\mathrm{MgCl}_{2}$

KC 1

$\mathrm{CaCl}_{2}$

$\mathrm{NaNO}_{3}$

$\mathrm{K}_{2} \mathrm{HPO}_{4}$

$\mathrm{Na}_{2} \mathrm{SiO}_{3} \cdot 9 \mathrm{H}_{2} \mathrm{O}$

TRIS

EDTA (disodium)

Li (Cl)

B $\left(\mathrm{H}_{3} \mathrm{BO}_{3}\right)$

Mo $(\mathrm{Na})$

$\mathrm{Mn}\left(\mathrm{Cl}^{-}\right)$

$\mathrm{Fe}\left(\mathrm{Cl}^{-}\right)$

Co $\left(\mathrm{Cl}^{-}\right)$

$\mathrm{Cu}\left(\mathrm{Cl}^{-}\right)$

I (KI)

Cyanocobalamine

Thiamine hydrochloride

Biotin
1.8 grams

0.6 grams

0.45 grams

0.06 grams

$30 \mathrm{mg}$

$10 \mathrm{mg}$

$1 \mathrm{mg}$

$10 \mathrm{mg}$

0.1 gram

$3 \mathrm{mg}$

$5 \mu g$

$0.6 \mathrm{mg}$

$25 \mu g$

$120 \mu g$

$100 \mu g$

$1.5 \mu g$

$0.1 \mu g$

$5 \mu g$

$0.01 \mu g$

$0.2 \mathrm{mg}$

$0.01 \mathrm{mg}$

Add distilled water to make $100 \mathrm{ml}$. medium 
of removing the radionuclides from the sea water. In addition, not only were they in able to remove nuclides, but they were also capable of selecting the desired nuclide. For example, $\underline{\text { K. }}$ rotundata selected only strontium while G. Simplex took up the yttrium when exposed to $\mathrm{Sr}^{90}-\mathrm{Y}^{90}$ solution.

The ability to accumulate and concentrate the cesium and strontium from the sea water medium was primarily through absorption with adsorption playing only a very minor role. Hence, when radioactive cells were placed in fresh media the loss of radioactivity to the medium was msall and a steady state was established very quickly, usually with 24 hours. Since absorption seems to be primarily responsible for the accumulation strontium and cesium by the phytoplankton it is of the utmost importance that more is learned, of the basic mechanisms involved. Before an ion can be absorbed, transport across the cell membrane must take place. Several mechanisms have been proposed for such a penetration but each involves an expenditure of energy, either directly or indirectly. The energy required for active transport which is linked with metabolic reactions is unknown. Scott (1954) stated that the mechanisms for $\mathrm{K}^{+}$and $\mathrm{Na}^{+}$in Ulva were independent of each other. It is also very probable that each ion requires a specific organic compound to act as a carrier for membrane penetration. For the most part, these are also unknown. Recently, Greenfield (1962) has found, in his investigation of a Pseudomonas, that alanine acts as such a carrier for calcium. A study of these mechanisms in the microorganisms will not only enrich our knowledge of them but may serve as a guide for the study of more complex forms. Since phytoplankton serves as food for other organisms, the site of the accumulation of the radioisotope will help predict its accumulation at other trophic levels. And now that it is known that phytoplankton are not confined to the euphotic zone (Kimbal1, Corcoran, Wood, 1963) and that the radioisotopes of cesium 
and strontium do penetrate to great oceanic depths (Bowen and Sugihara, 1960, Miyake, et al 1962), this study becomes still more important. The use of cultures for this type of study of fundamentals is ideal but extrapolation of these results to the open sea environment should not be done without first making a thorough in situ investigation.

\section{THE SCIENTIFIC STAFF}

Dr. E. F. Corcoran

Dr. H. B. Moore

John F. Kimba11, Jr.

Elizabeth C. Alexander
Principal Scientific Investigator Plankton Consultant

Plankton Culturist

Plankton Culturist

\section{PUBLICATIONS}

Corcoran, E. F. and J. F. Kimba11, Jr. The uptake, accumulation and exchange 1962 of strontium-90 by open-sea phytoplankton. Radioecology. Reinhold Publishing Corporation, New York.

Kimbal1, J.F., Jr., E. F. Corcoran and E. J. F. Wood. Chlorophyll containing microorganisms in the aphotic zone of the oceans. Bull. Mar. Sci. Gulf \& Carib., $\underline{13}(4): 574-577$.

\section{REFERENCES CITED}

Bernhard, M. The uptake, accumulation and loss of radioactive material

1962 by bacteria. IAEA Panel on Co-ordination of Research Projects on Radioactivity in the Marine Environment - Vienna.

Bowen V. T. and T. T, Sugihara. Strontium-90 in the "mixed layer" of 1960 the Atlantic Ocean. Nature, 186:71-72. 
Chipman, W. A., Rice, T. R., and Price, T. J. Accumulation of radioactivity

1953 by marine invertebrate animals. U. S. Fish and Wildife Service Radioisotope Laboratory, Progress Report, April, 1953. Accumulation of fission products by marine plankton, fish,

1954 and shellfish. U. S. Fish and Wildlife Service Radioisotope Laboratory, Progress Report, July-December, 1954.

Donaldson, L., Seymour, A. H., Held, E. E., Hines, N. O., Lowman, F. G., 1956 and Wilander, A. D. Survey of Radioactivity in the sea near Bikini and Eniwitok atolls. June 11-24. Applied Fisheries Lab., Univ. of Wash., Seattle, Wash.

Greenfield, L. Metabolism and concentration of calcium and magnesium 1963 and precipitation of calcium carbonate by a marine bacterium. Ann. New York Acad. Sci. 109:23-45.

Johnson, G. T. and G. C. Kyker. Fission-product and cerium uptake by

1961 bacteria, yeasts and molds. J. Bacteriol. 81(5):733-740.

Kimba11, J.F., Jr., E. F. Corcoran, E. J.F. Wood. Chlorophyll-containing 1963 microorganisms in the aphotic zone of the oceans. Bu11. Mar. Sci. Gulf \& Carib., $13(4): 574-577$.

Lackey, James B. The suspended microbiota of the Clinch Riveriand 1957 adjacent waters in relation to radioactivity in the summer of 1956. Oak Ridge National Laboratory Report No. 2410. Reprinted as: Tech. Paper 145, Florida Engineering and Indus, Exp. Sta. 1958.

Lanskaya, L. A., The Division Rates of Phytoplankton Algae of the Black

1961 Sea Culture. Symposium on Microbiology. Charles C. Thomas, Springfield, I11. p. 127-132. 
Lear, D. W. and C. H. Oppenheimer, Jr. Biological removal of radio-

1962 isotope $\mathrm{Sr}^{90}$ and $\mathrm{Y}^{90}$ from sea water by marine microorganisms. Limnol, and Oceanog. Supp. to Vol, VII:xliv.

Miyake, Y., K. Saruhashi, Y. Katsuragi, and T. Kanazawa. Penetration of

$1962 \mathrm{Sr}^{90}$ and $\mathrm{Cs}^{137}$ in deep layers of the Pacific and vertical

diffusion rate of deep water. Jour. of Radiation Res., 3:141-147.

Morgan, G. B. The absorption of radioisotopes by certain microorganisms.

1961 Quart. Jour.Fla.Acad.Sci. 24 (2):94-100.

Rice, T. R. The accumulation and exchange of strontium by marine planktonic

1956 algae. Limnol. Oceanogr. 1 p.123-138.

The effects of atomic radiation on oceanography and fisheries.

1957 Publication No. 551 National Academy of Sciences - National Research Council.

1959 Radioactive Waste disposal from nuclear-powered ships National Research Council - Publication 658.

Rocco, G. G. and W. S. Broecker. The vertical distribution of Cs 137 1963 and $\mathrm{Sr}^{90}$ in the Oceans.

Rothstein A., and A. D. Hayes. The relationship at the cell surface

1956 to metabolism. XII. The cation binding properties of yeast cell surface. Archiv. Biochem. Biophys, 63:87-99.

Scott, R. Cesium accumulation by marine algae.Proc. 2nd Radioisotope

1954 Conf. Oxford I Med. and Physiol. Applications 373-380.

Thomas, W., D.W. Lear, Jr. and F. T. Haxo. Uptake by the marine

1962 dinoflagellate. Gonyaulax polyedra of radioactivity formed during an underwater nuclear test. Limnol, and Oceanog. Supp. to Vo1.VII: 1xvi-1xxi. 
Samles, A. A. and L. Salmon. Determination by radioactivation of sma11 amounts of rubidium and cesium in sea water and related material of geochemical interest. Analyct. $80: 37$.

Watts, J.R. and R. S. Harvey. Uptake and retention of Cs ${ }^{137}$ by a blue1963 green alga in continuous flow and batch culture systems. Limno1. Oceanogr. $\underline{8}(1): 45-49$.

Williams, L. G., and Swanson, H. D. Concentration of cesium 137 by algae. Science $127: 187-188$.

Williams, L. G. Uptake of cesium 137 by cells and detritus of Euglena

1960 and Chlorella. Limnol. Oceanogr. $\underline{5}(3): 301-311$.

Wtikamp, M. Uptake, concentrations and release of cobalt and cesium by

1962 solid fungi. Health Physics Division, Oak Ridge National Laboratory, Oak Ridge, Tenn.

Zharova, T. W. Accumulation of radioactive isotope of strontium.

1961 Cesium and cerium by some bacteria. Mikrobiologiya. 30(5):713-716. 

